\section{Commentary: There is no "I'" in team}

\author{
Anthony L. Estrera, MD, FACS
}

Although E. Stanley Crawford provided us the guiding principles for open repair of thoracoabdominal aortic aneurysms (TAAAs), much has been accomplished since the 1980 s in the areas of surgical adjuncts, anesthesia, and critical care. ${ }^{1-3}$ This has led to improved outcomes, especially when one considers the most dreaded complication: spinal cord injury. Although we, as surgeons, frequently focus on the achievements of the surgeon, much of this work could not have happened without the efforts of many, always working as a team.

It may sound cliché to say that "surgery is a team sport," but this concept is no better exemplified than with regard to open TAAA repairs. In 1999, when Dr Hazim Safi decided to build a new program with a focus on open TAAA repair at the University of Texas Medical School at Houston and Memorial Hermann Hospital, he had a very simple formula: bring a team. A team that included the skills required to perform open TAAA repair-cardiovascular anesthesia, perfusion, nursing, and critical care. These were standard components of any cardiovascular team, but unique was the extensive experience that the group had developed together as a team.

In this report, from the St Bartholomew's Hospital group in London, the authors detail their approach to the management of the extent 2 TAAA. ${ }^{4}$ Many of the techniques described were not novel but were adopted over the extensive experience gained by the senior author (A.O.) over the past 15 years. Some of these techniques warrant comment.

- Proximal aortic crossclamping: The authors correctly emphasize this point. If this cannot be accomplished

\footnotetext{
From the Department of Cardiothoracic and Vascular Surgery, McGovern Medical School at The University of Texas Health Science Center at Houston (UTHealth) and Memorial Hermann Hospital, Houston, Tex.

Disclosures: Dr Estrera is a consultant for W. L. Gore \& Associates.

The Journal policy requires editors and reviewers to disclose conflicts of interest and to decline handling or reviewing manuscripts for which they may have a conflict of interest. The editors and reviewers of this article have no conflicts of interest.

Received for publication July 27, 2020; revisions received July 27, 2020; accepted for publication July 31, 2020; available ahead of print Aug 12, 2020.

Address for reprints: Anthony L. Estrera, MD, FACS, Department of Cardiothoracic and Vascular Surgery, McGovern Medical School at UTHealth, 6400 Fannin St, Ste. \#2850, Houston, TX 77030 (E-mail: Anthony.L.Estrera@uth.tmc.edu) JTCVS Techniques 2020;3:39-40

2666-2507

Copyright (C) 2020 The Authors. Published by Elsevier Inc. on behalf of The American Association for Thoracic Surgery. This is an open access article under the CC BY-NCND license (http://creativecommons.org/licenses/by-nc-nd/4.0/).

https://doi.org/10.1016/j.xjtc.2020.07.034
}

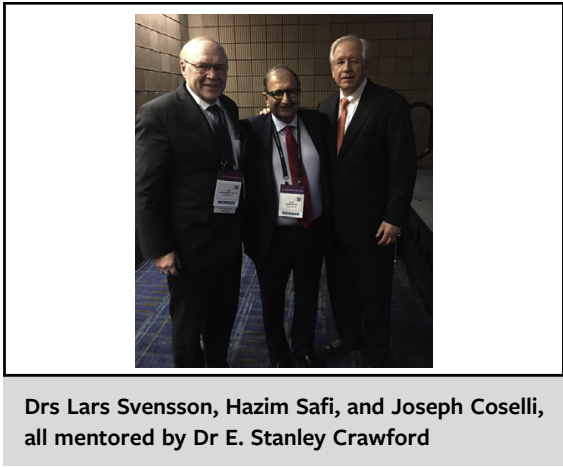

\section{CENTRAL MESSAGE \\ Like all major cardiovascular procedures, it takes a team to achieve success.}

safely, then use of full cardiopulmonary bypass will be required, usually with circulatory arrest, to perform the proximal anastomosis.

- Left heart bypass (LHB): This is the authors' primary approach for distal circulatory support during the crossclamping period. The authors report drainage cannulation from the left inferior pulmonary vein with inflow to the left common femoral artery. Since oxygenation is dependent on native respiratory function, it should be noted that the inferior pulmonary vein cannula should be inserted into the left atrium deep enough to ensure the blood drained is oxygenated. Regarding arterial inflow via the femoral artery, eliminating the distal clamp usually allows enough perfusion to prevent distal ischemia. Moreover, the authors report the use of a centrifugal pump with no mention of a heat exchanger. We prefer to also add a heat exchanger to the circuit to maintain core temperature between $33^{\circ} \mathrm{C}$ and $34^{\circ} \mathrm{C}$. It is not unusual for the temperature to drop below $33^{\circ} \mathrm{C}$, which can lead to ventricular dysrhythmias. It is the heat exchanger that requires adequate anticoagulation. The most important point with LHB for distal aortic perfusion is the fact that proximal and distal aortic pressures must be continually monitored. This is where the team becomes critical. A continual appreciation of volume status, blood pressure, and amount of bleeding must be maintained by the surgeon, anesthesiologist, and perfusionist at all times. The information must be communicated and adjustments made by the team on a continual basis. In some ways, the use of LHB is more complex than use of full cardiopulmonary bypass for of this reason.

- Cell salvage: The details of this were not provided by the authors. This again remains a very important role 
assumed by the anesthesiologist and perfusion. During the opening of the distal thoracic and abdominal segments, massive bleeding may occur-even with distal infrarenal abdominal aortic clamping. Until the intercostal and lumbar arteries and visceral and renal arteries are controlled, significant bleeding may occur. It remains imperative to have a method of blood salvage. We use cell salvage, which is filtered and recirculated via a rapid infusion device. Since no reservoir is used with LHB, this become crucial.

- Proximal anastomosis: When performing the proximal anastomosis, the authors report the proximal aorta is completely transected. It should be noted that the aorta should also be separated from the esophagus, to prevent fistula. At this location, this is why the inclusion technique for the anastomosis is avoided.

- Distal anastomosis: We also perform the distal anastomosis after the proximal anastomosis, but before the intercostal, visceral, and renal vessels, to expeditiously provide pulsatile flow to the pelvic circulation. This may reduce the duration of spinal cord ischemia.

- Neuromonitoring: The authors use motor-evoked potential (MEP) monitoring for the procedure but still reattach intercostal arteries (ICAs) that are patent between T8 and L1. Although we too will reattach ICAs independent of alternation in MEPs monitoring since we have demonstrated their importance in preventing delayed paraplegia, ${ }^{5}$ it alters our conduct of the procedure. Early loss of MEPs will lead us to reattach the ICAs earlier in the procedure-before the visceral and renal reattachments.
The authors are to be congratulated for providing a detailed description of their approach to the open repair of the TAAA extent 2 . The technique described here has been adapted by the senior author's (A.O.) experiences demonstrated to him by his mentors and colleagues before him. However, not appreciated in this detailed step-bystep description is the team work required for this undertaking. Open repair of extent 2 TAAA is a difficult procedure, fraught with the potential for significant complications. As such, it requires a well-synchronized team to achieve success. Although I focus on this disease entity, the extent 2 TAAA, the importance of the team in cardiovascular surgery can be applied to everything we do as a specialty. All of it can be hard. It is amazing what we can accomplish as a team, just as long as we remember there is no "I" in team.

\section{References}

1. Svensson LG, Crawford ES, Hess KR, Coselli JS, Safi HJ. Experience with 1509 patients undergoing thoracoabdominal aortic operations. J Vasc Surg. 1993;17: 357-68; discussion 368-70.

2. Estrera AL, Sandhu HK, Charlton-Ouw KM, Afifi RO, Azizzadeh A, Miller CC III, et al. A quarter century of organ protection in open thoracoabdominal repair. Ann Surg. 2015;262:660-8.

3. Coselli JS, LeMaire SA, Preventza O, de la Cruz KI, Cooley DA, Price MD, et al. Outcomes of 3309 thoracoabdominal aortic aneurysm repairs. J Thorac Cardiovasc Surg. 2016;151:1323-37.

4. Lopez-Marco A, Adams B, Oo AY. Thoracoabdominal aneurysmectomy: operative steps for Crawford extent II repair. J Thorac Cardiovasc Surg Tech. 2020;3:25-36.

5. Afifi RO, Sandhu HK, Zaidi ST, Trinh E, Tanaka A, Miller CC III, et al. Intercostal artery management in thoracoabdominal aortic surgery: to reattach or not to reattach? J Thorac Cardiovasc Surg. 2018;155:1372-8.e1. 